\title{
THE INTER-AMERICAN COFFEE AGREEMENT
}

\author{
Paul C. Daniels*
}

\section{ECONOMIC BACKGROUND}

The importance of coffee in the economic life of the American republics can hardly be exaggerated. It is consumed in all the American republics in appreciable quantities, and is regularly produced for export in I4 of the American republics. ${ }^{1}$ More than many other export commodities, the proceeds derived from its sale abroad are distributed widely among the inhabitants of the country of export. It is a crop so closely allied to the day-to-day living conditions of so many people that it constitutes an admirable economic barometer for those countries where its production is important. The huge export crops of Brazil and Colombia are familiar to all of us; but perhaps less well known is the fact that in normal times coffee represents approximately $90 \%$ by value of all exports from the Republic of El Salvador. In other words, not only is the volume of trade tremendous in the larger producing countries, but the proportion of coffee in the export trade of many of the smaller producing countries is very high. It is apparent, therefore, that the prosperity and well-being of

* A.B., 1924, Yale University. American Foreign Service Officer since 1927, stationed in Chile, Colombia, Bolivia, Nicaragua and Venezuela; assigned to Department of State, Washington, since 1939; Assistant Chief, Division of the American Republics, since 1940; Chairman, Inter-American Coffec Board, since April I7, I94I.

${ }^{2}$ Vatue of Coffee Imports from Latin American Republics to the United States, 1939 and $1940 *$

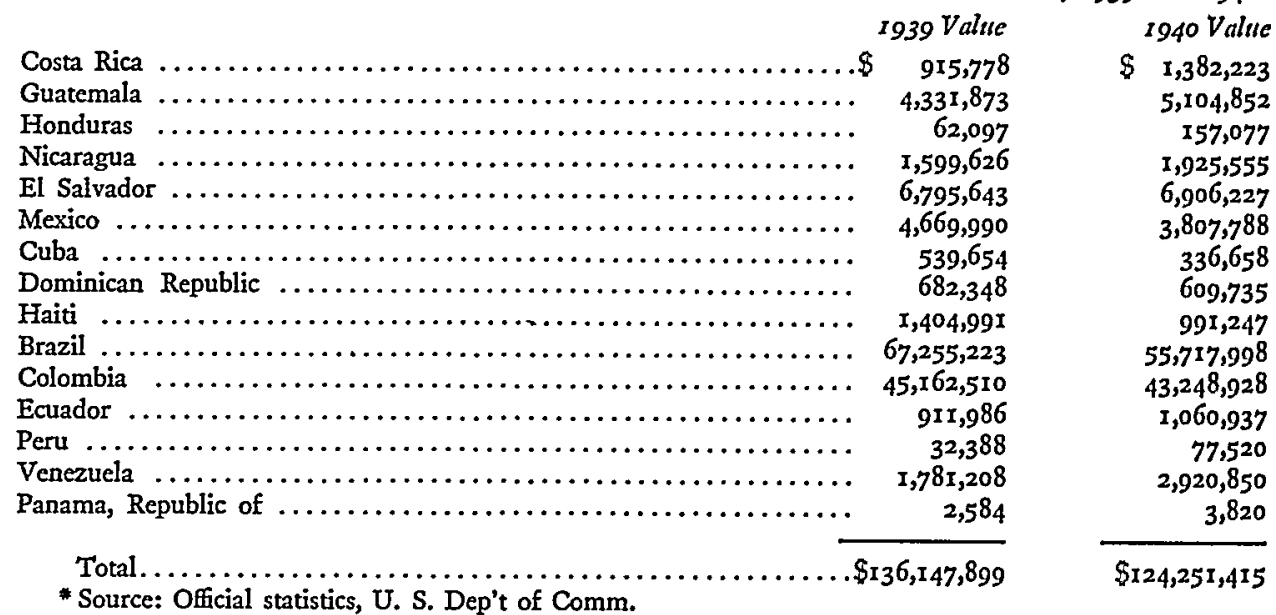


the American coffee-producing republics depend in large measure on the maintenance of stable market conditions for the crop at reasonable prices. ${ }^{2}$

The economic benefits to be derived from a prosperous export trade in coffee are to be measured not only in terms of the direct proceeds received by exporters and growers, but also in a variety of indirect ways. In some countries revenues derived from the taxation of coffee constitute an important item of governmental income. On the other hand, depressed export prices for coffee greatly aggravated the acute foreign exchange difficulties experienced in recent years by most of the American republics. To the extent that improved marketing conditions bring about increased foreign exchange availabilities in those countries, to that extent local currencies are strengthened and problems of arbitrary and enforced exchange controls alleviated. Finally, increased purchasing power in the producing countries, combined with increased availabilities of dollar exchange, makes it possible for those countries to increase proportionately their purchases of American-manufactured goods and foodstuffs, and to service more adequately their dollar financial obligations, whether commercial or governmental. In other words, coffee exemplifies perhaps as much as any other commodity the essential nature of international trade, i.e, an exchange of goods rather than a mere process of selling. If a normal market for coffee ceases to exist, normal two-way trade becomes unbalanced and serious consequences result.

It is well to bear in mind that the international trade in coffee has been conducted on an "abnormal" basis for many years. In I93r Brazil commenced its current program of coffee destruction, in order to avoid the accumulation of surpluses, and in that way has attempted to prevent the price of exported coffee from falling to ruinous levels. Other producing countries have naturally benefited by this program. From June I93I up to August I5, I94I, there had been officially destroyed in Brazil a grand total of $72,5^{8} 3,000$ bags of 60 kilograms, equivalent to over $9,580,956,000$ pounds. ${ }^{3}$ This destruction is still continuing today. It is apparent that under conditions such as these the coffee trade can hardly be considered as having been "normal" at any time during the past ten years.

Cognizant of their common problem, certain coffee-producing countries appointed delegates to a Coffee Conference which was held at Bogota, Colombia, in October 1936. At that Conference various proposed measures intended to be of benefit to the coffee trade were discussed, including the highly controversial questions of export quotas and price controls. It was at this Conference that a resolution was approved

"Frve Major Imports Into the United States from Lattn America, 1939 and I940*

r939 Value

Coffee $\ldots \ldots \ldots \ldots \ldots \ldots \ldots \ldots \ldots \ldots \ldots \ldots \ldots \ldots \ldots \ldots \ldots, 200,000$

Cane sugar $\ldots \ldots \ldots \ldots \ldots \ldots \ldots \ldots \ldots \ldots \ldots \ldots \ldots \ldots, 75,000,000$

Copper**............... 30,100,000

Bananas ................. $28,800,000$

Crude petroleum and semi-finished

oils ................. 23,300,000

- Source: International Reference Service, U. S. Dep't of Comm. (May, I94I).

* Chiefly unrefined metal for refining and reexport.

${ }^{3}$ See N. Y. Coffee and Sugar Exchange, Inc., Daily Bulletin, Sept. I2, 194x.
1940 Value

Coffee $\ldots \ldots \ldots \ldots \ldots \ldots \ldots \ldots \ldots \ldots \ldots \ldots \ldots \ldots \ldots \ldots, 3,00,000$

Cane sugar $\ldots \ldots \ldots \ldots \ldots \ldots \ldots \ldots \ldots \ldots \ldots \ldots \ldots \ldots \ldots, 6,700,000$

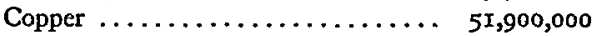

Crude petroleum and semi-finished

oils $\ldots \ldots \ldots \ldots \ldots \ldots \ldots \ldots \ldots \ldots \ldots \ldots \ldots \ldots \ldots \ldots, 47,600,000$

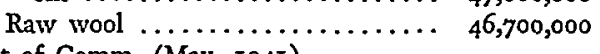


creating the Pan American Coffee Bureau, a central organization representing the coffee-producing American republics, with permanent offices in New York City. Although it was originally intended that all of the coffee-producing American republics should join in the support and maintenance of this new Bureau, some of these countries have so far failed to become members. ${ }^{4}$

No definitive agreements having been reached at the Bogota Conference regarding the vital problems of export quotas and price controls, and since some producers apparently felt that some such measures were called for because of existing market conditions, a second Pan American Coffee Conference was convened at Havana, Cuba, in August 1937. At this Conference there was launched the cooperative advertising and promotion campaign which has since been conducted by the Pan American Coffee Bureau. This campaign has been advertising coffee as a beverage, rather than particular brands or types of coffee, and has been financed by an advertising tax of five cents per bag imposed by the countries members of the Bureau. The United States coffee trade cooperated in the formulation and operation of this campaign, and it met with no objections from official Washington. However, at Havana as at Bogota, no decisions were reached regarding export quotas and price controls.

About two months after the close of the I937 Havana Conference, Brazil, faced with the gradual loss of her coffee export markets to competitors due to her efforts to maintain firm export prices, decided to change this policy for one of seeking wider markets and greater volume at the expense of firmer prices. As the result of this change of policy, the price of Brazilian coffee on the New York market abruptly declined in the closing months of 1937, with consequent depressing effects on the prices for other coffees. At the same time, the volume of coffee exports from Brazil showed a great increase in $193^{8}$ over those of the previous year.

This unstable condition in the coffee market, characterized by excess supplies, destruction of coffee surplus in Brazil, and depressed prices, continued up to the outbreak of the European war in September I939. From that point on the situation deteriorated even further. The abrupt curtailment of the important European market due to war conditions greatly aggravated the surplus problem and pushed prices down still further to ruinous levels. With the normal market for around 10,000,000 bags of coffee almost completely cut off, there developed uncontrolled competitive efforts to dump in the United States market-the only large and completely accessible market still open-excessive quantities of coffee at disastrous prices. The outlook for coffee producers in the early months of r940 could hardly have been less promising.

Confronted by conditions far worse than those which they had previously experienced, the coffee-producing American republics once more convened for the Third Pan American Coffee Conference, held in New York during the months of

\footnotetext{
- As of Oct. I, I94r, the following countries were members of the Pan American Coffee Bureau: Brazil, Colombia, El Salvador, Venezuela, Mexico, Costa Rica and Cuba. The following countries, although producers and exporters of coffee, were not members: Guatemala, Honduras, Nicaragua, Haiti, Dominican Republic,. Ecuador and Peru.
} 
June and July I940. Once more the same difficult problems of export quotas and price controls were debated day after day. The delegates to the Conference seemed to feel that to enforce some sort of control plan to restore more orderly conditions in the coffee market, the cooperation of the United States would be desirable, if not essential. This cooperation, particularly with respect to the control of imports of non-American coffees, was requested by the President of the Third Pan American Coffee Conference in a letter addressed to the Secretary of State; and Secretary Hull in his reply, dated June 24 , r940, stated in part as follows:

Your inquiry has been the subject of consultation between representatives of the various interested Departments and agencies of the United States Government, and in accordance with their conclusions I am pleased to inform you that the Government of the United States understands the reasons for the request that you have made and is sympathetic with that request, and that this Government would be willing to cooperate with the Third Pan American Coffee Conference in taking the necessary steps, which may involve recommendation of action to the Congress of the United States, to implement a plan of control over the production and marketing of coffee.

It will be understood, of course, that this willingness to cooperate is dependent upon the ability of the United States Government to approve the nature and the details of the coffee control program which would be devised. In this connection, this Government would desire to be officially represented in the negotiations of any control program for coffee, and also to be represented on any body which would be established to administer the plan so set up. I should also point out that the United States Government has always taken the position, in connection with the negotiation or discussion of international commodity agreements, that an essential provision of any such agreement is a recognition of the need for protection of the legitimate interests of consumers as well as of producers, and it would expect that any coffee agreement would contain such a provision.

Not only was the sympathetic attitude of the United States made manifest by the aforesaid communication from the Secretary of State, but in addition the Department of State, at the invitation of the Conference, sent a representative to be present at the meetings in the capacity of observer.

The net results of the New York Conference, however, were hardly more concrete than those of the earlier ones at Bogota and Havana. While a tentative plan for export quotas was drawn up at the Conference, it failed to obtain the approval of all the governments, and there still seemed to be no final and effective solution to the problem. Meanwhile, conditions in the coffee market were steadily becoming worse, with new crops coming on the market shortly and war conditions becoming intensified.

\section{INTER-Governmental Negotiations-Origin and Background}

Turning aside now from the economic conditions antecedent to the negotiation of the Inter-American Coffee Agreement, let us consider briefly the juridical framework within which these negotiations were conducted. At the Inter-American Conference for the Maintenance of Peace held at Buenos Aires in 1936 there was created a consultative procedure to be availed of by the American states in times of emergency. At the regular Inter-American Conference held at Lima in $193^{8}$ this con- 
sultative procedure was further elaborated, and provision was made for the Foreign Ministers of the American republics to meet together for purposes of consultation whenever the peace and security of the Western Hemisphere might be endangered. The outbreak of the war in September 1939 created such an emergency. Accordingly, with extraordinary rapidity, the consultative procedure was put into motion for the first time in history, and on September 23, 1939, there was convened the First Meeting of the Ministers of Foreign Affairs of the American Republics at Panama. At this meeting a number of resolutions and declarations of far-reaching importance were approved, in the fields of international law, neutrality, and international trade and finance. The basic and underlying motif was the political and economic solidarity of the Americas.

Of particular importance to our present study was the approval on October 3 , 1939, of the Resolution on Economic Cooperation. This Resolution reads in part as follows: 5

The Meeting of the Foreign Ministers of the American Republics

RESOLVES:

I.-In view of the present circumstances, to declare that today it is more desirable and necessary than ever to establish a close and sincere cooperation between the American Republics in order that they may protect their economic and financial structure, maintain their fiscal equilibrium, safeguard the stability of their currencies, promote and expand their industries, intensify their agriculture and develop their commerce.

2.- To create an Inter-American Financial and Economic Advisory Committee consisting of twenty-one (2I) experts in economic problems, one for each of the American Republics, which shall be installed in Washington, D. C., not later than November 15, r939, and which shall have the following functions: ...

(b) To study the most practical and satisfactory means of obtaining the stability of the monetary and commercial relationships between the American Republics. . . .

(d) To study and propose to the Governments the most effective measures for mutual cooperation to lessen or offset any dislocations which may arise in the trade of the American Republics and to maintain trade among themselves, and as far as possible, their trade with the rest of the world, which may be affected by the present war. ...

Pursuant to the above resolution, the Inter-American Financial and Economic Advisory Committee was duly constituted in Washington in November 1939, and has been meeting regularly since that date in the offices of the Pan American Union.

Following the Panama Meeting the war continued and in I940 assumed greater magnitude and intensity, with increased threats to the political and economic security of the Western Hemisphere. Accordingly, in July I940 there was convened the Second Meeting of the Ministers of Foreign Affairs of the American Republics, this time at Havana, Cuba. Once more important decisions were reached of a political and economic character, most of which need not concern us here. Of particular importance for our present purposes was the approval of the Resolution on Economic and Financial Cooperation. This Resolution, after reciting the declarations of the

\footnotetext{
${ }^{5}$ For full text, see Report of the Delegate of the United States of America to the Meeting of the Foreign Ministers of the American Republics (Washington, 1940).
} 
First Consultative Meeting and the agreement to create the Inter-American Financial and Economic Advisory Committee, reads in part as follows: ${ }^{6}$

WhEREAS: . . .

3. The war now in progress has increased the disruption in the channels of international commerce and the curtailment of markets for certain products of the Americas;

4. The existence of surpluses of commodities, the exportation of which is essential to the economic life of the countries of the Americas, is economically, socially, financially, and in other respects a matter of great importance to the masses of the population, and especially to those groups participating in the production and distribution of wealth in each country, and, finally, to the governments of the entire continent;

5. It must be anticipated that these difficulties will exist as long as the war continues and that some of them, as well as other new ones, will exist after the war ends; ...

The Second Meeting of the Ministers of Foreign Affairs of the American Republics

Resolves: ...

Two. To strengthen and expand the activities of the Inter-American Financial and Economic Advisory Committee as the instrument for continuing consultation among the American republics with respect to economic and trade matters and arrangements, having in mind especially the immediate situations which must be met as a result of the curtailment and changed character of important foreign markets. For the purpose of dealing with special problems, there may be organized subcommittees, composed of representatives of the interested countries, which should meet at such places as may be deemed most appropriate for their effective functioning.

Three. Specifically, to instruct the said committee that it proceed forthwith:

(a) To cooperate with each country of this continent in the study of possible measures for the increase of the domestic consumption of its own exportable surpluses of those commodities which are of primary importance to the maintenance of the economic life of such countries;

(b) To propose to the American nations immediate measures and arrangements of mutual benefit tending to increase trade among them without injury to the interests of their respective producers, for the purpose of providing increased markets for such products and of expanding their consumption;

(c) To create instruments of inter-American cooperation for the temporary storing, financing, and handling of any such commodities and for their orderly and systematic marketing, having in mind the normal conditions of production and distribution thereof;

(d) To develop commodity arrangements with a view to assuring equitable terms of trade for both producers and consumers of the commodities concerned; ...

\section{Negotiation of the Inter-American Coffee Agreement}

We have now surveyed the economic developments affecting coffee leading up to the second half of I $94^{\circ}$ as well as the legal procedures arrived at by inter-American negotiation in order to deal with such problems. The next step was to utilize the machinery which had been created in order to meet the urgent economic necessities which had arisen. No time was lost. As soon as possible after the closing of the Havana Meeting the Subcommittee on Coffee, which had already been created by the Inter-American Financial and Economic Advisory Committee, went seriously to work on the drawing up of an agreement intended to restore orderly marketing

\footnotetext{
- For full text, see Second Meeting of the Ministers of Foreign Afjairs of the American Republics, Habana, July 21-30, 1940, Report of the Secretary of State (Washington, 1941).
} 
. conditions in the coffee trade. These negotiations lasted from August until November 28, r940, the date on which $\mathrm{x}_{4}$ American coffee-producing republics and the United States signed the Inter-American Coffee Agreement.

The outstanding feature of this new agreement was the fixing of basic quotas for the United States market. There were likewise established quotas for the market outside the United States, although during war conditions that has been a relatively academic provision of the Agreement. Lengthy debates and arguments were necessary before it was possible to reach agreement among all I5 participating countries as to the total amount of these quotas and as to the distribution among producing countries. Some countries felt that in order to establish the quotas the total coffee production of each country should serve as the basis of calculation. This method would obviously be of benefit to those countries which had previously been shipping a high percentage of their production to European markets now closed by the war. Other countries which had previously been shipping a high percentage of their coffee exports to the United States market believed that the quotas for this market should be determined on the basis of previous trade. It became apparent that acceptance of either of these bases for calculating the proposed new quotas would fail to meet with unanimous acceptance. Eventually the quotas as finally approved by all the governments represented a compromise based on negotiation, rather than the application of a mathematical formula. The total amount of the basic quotas for the participating coffee-producing countries was established at 15,545,000 bags of 60 kilograms; and it was agreed that the United States would undertake to limit imports of coffee from other sources to a total basic quota of 355,000 bags. There was created by the Agreement a new organization, the Inter-American Coffee Board, to be charged with the primary function of adjusting the basic quotas in accordance with the requirements of the market. It is interesting to note that the total amount of annual coffee imports permitted by the basic quotas, $15,900,000$ bags, is a figure several hundred thousand bags in excess of any previous year of coffee imports into the United States. In other words, the newly-established quota system was not intended to be restrictive in the sense of curtailing normal imports; rather, it was intended to maintain normal conditions in the United States market by holding off this market an abnormal surplus of some ro million bags.

The newly-created Inter-American Coffee Board consists of one delegate from each of the 15 participating governments. Voting power among the producing countries was distributed roughly in proportion to their respective importance as coffee producers, with the result that Brazil was given nine votes, Colombia three votes, and each of the other producing countries one vote. The United States, because of its important interest as a consumer, was given twelve votes. Accordingly, on a Board of fifteen delegates the total number of votes is thirty-six, of which the United States has one third.

Normal adjustments of the quotas for the United States market, in accordance with Article III of the Inter-American Coffee Agreement, are not to exceed five 
percent of the basic quotas at any one time nor to be made more frequently than once every six months-the purpose of these provisions being to minimize so far as possible uncertainties and speculation which might otherwise characterize the regular meetings of the Board. However, as an essential measure of protection for the United States, there was included an emergency provision under Article VIII, providing that

In the event that there should be foreseen an imminent shortage of coffee in the United States market in relation to its requirements, the Inter-American Coffee Board shall have the authority, as an emergency measure, to increase the quotas for the United States market, in proportion to the basic quotas, up to the quantity necessary to satisfy these requirements even though in this manner the limits specified in Article III may be exceeded. Any member of the Board may request such an increase and the increase may be authorized by a one-third vote of the Board.

Without elaborating in any further detail the 26 separate articles of the InterAmerican Coffee Agreement, it should be emphasized that the unique and unprecedented feature of this cooperative arrangement is the provision for consumer representation in an international agreement intended to stabilize the market for an important raw material. Commodity arrangements in the past having similar objectives, such as those for tin, rubber and tea, were essentially agreements among producers to control markets. The participation of the United States in the InterAmerican Coffee Agreement marks a new milestone in the progress of international economic thinking. It is concrete evidence of the fact that terms of trade must be equitable for consumer as well as producer, and that both should be cognizant of the vital needs of each other.

\section{Ratification by the United States}

In the course of the negotiations preceding the signature of the Inter-American Coffee Agreement it was an open question during much of this period as to whether it would be possible for the proposed new program to be embodied in an executive agreement between the various governments, or whether it should be in the form of a treaty subject to ratification. In order to allow each government freedom of action to determine this point in accordance with its own legal and constitutional requirements, this point was not formally decided by the negotiators and the InterAmerican Coffee Agreement was so drafted as to lend itself to either procedure. Following its signature on November 28, 1940, it soon developed that its submission in the form of a treaty seemed better to meet the requirements of the participating countries. This was true in the case of the United States, in the absence of any broad legislative authority for the conclusion of an international commodity agreement of this character. Accordingly, President Roosevelt addressed a communication to the Senate of the United States under date of January 9, I94I, transmitting the text of the Agreement, together with an accompanying report of the Secretary of State, with a view to receiving the advice and consent of the Senate to ratification. The Agree- 
ment was referred to the Senate Committee on Foreign Relations, which submitted a favorable report thereon under date of January 3 I, 194I. ${ }^{7}$

In spite of the heavy pressure on the members of the Senate Committee on Foreign Relations during January and February due to the tremendous public interest at that time in the passage of the Lend-Lease Bill, the Committee set aside time for a hearing on the Coffee Agreement and gave the matter its thoughtful attention. Following its favorable report to the Senate, the Agreement came up for debate on the floor of the Senate on February 3, I94I, and was approved without serious opposition. Shortly thereafter the President affixed his signature to the instrument of ratification.

In the meantime the question had been raised as to whether the Treasury Department, through the Bureau of Customs, would have sufficient legal authority under the new treaty to exclude from the United States arrivals of coffee in excess of the established quotas. In order to avoid any question arising on this point, a bill was drafted and submitted to both Houses of Congress providing that during the continuation in force of the obligations of the United States under the Inter-American Coffee Agreement, no coffee imported from any foreign country might be entered for consumption except as provided in the said Agreement. This bill passed both Houses of Congress and was approved by the President on April II, 1941. ${ }^{8}$

With the passage of this enabling legislation there was no further question regarding the legal authority of the Government to discharge its obligations under the Inter-American Coffee Agreement, and accordingly the instrument of ratification of the United States was deposited with the Pan American Union on April 14, 1941.

\section{ENTRy of the Agreement into EfFect}

By that time nine governments had deposited their instruments of ratification or approval, and because of the urgent need for action these governments brought the Agreement into effect among themselves by means of a protocol signed on April 15, I94I. ${ }^{9}$ The Inter-American Coffee Agreement thereupon became legally binding on the United States and the other countries which had signed the protocol, and for practical purposes achieved the major objective with respect to all countries. Even though the countries which had not yet signed the protocol could not properly be

\footnotetext{
${ }^{7}$ The Inter-American Coffee Agreement, Exec. REP. No. 2, 77th Cong., Ist Sess. This document contains in convenient form the full text of the Inter-American Coffee Agrecment, an analysis of its provisions, the report of the Subcommittee of the Senate Committee on Forcign Relations, the report of the Secretary of State, and the transmitting communication of the President.

${ }^{8}$ Pub. L. No. 33, 77th Cong., Ist Sess. (I94I). Of interest in this connection is the report of the House Committee on Ways and Means, dated March 26, 1941, Implementing the Inter-American Coffee Agreement, H. R. REP. No. 330, 77th Cong., Ist Sess. (194 I).

${ }^{\circ}$ The Inter-American Coffee Agreement, Art. XX, par. 3, reads as follows: "If, within ninety days from the date of signature of this Agreement, the instruments of ratification or approval of all the signatory Governments have not been deposited, the Governments which have deposited their instruments of ratification or approval may put the Agreement into force among themselves by means of a Protocol. Such Protocol shall be deposited with the Pan American Union, which shall furnish certified copies thereof to each of the Governments on behalf of which the Protocol or the present Agrcement was signed."
} 
considered legally bound by the terms of the Agreement, the United States was bound to limit imports of coffee from those countries in accordance with its own treaty obligations. This procedure made it possible for the control of coffee imports into the United States to be applied simultaneously to all coffee, rather than the gradual extension of such control country by country, which would have been grossly unfair and brought about a chaotic condition.

An interesting point of law arose in this connection. There were three signatory countries which had not yet become legally bound by the Coffee Agreement, which likewise were parties to trade agreements in force between them and the United States. In each of these trade agreements there was contained a commitment to the effect that the United States would impose no quantitative restriction on imports of coffee from those countries. It will be seen that the United States, legally bound by treaty obligations to impose quantitative restrictions on coffee imports from a given country and at the same time bound by its trade agreement obligations to refrain from the imposition of such restrictions, might find itself in an awkward dilemma. In order to overcome this difficulty specific authorization was sought from the countries in which this problem had arisen, and a specific waiver of trade agreement rights was obtained in each case. With respect to trade agreement obligations towards countries already bound by the provisions of the Inter-American Coffee Agreement, Article XXI of the Agreement itself provided the necessary waiver. ${ }^{10}$

\section{Organization of the Inter-American Coffee Board}

On April I7, I94I, two days after the signature of the protocol bringing into effect the Agreement, the Inter-American Coffee Board convened for the first time at the Pan American Union in Washington. At this first meeting the necessary steps in the organization of the Board were taken. A Chairman and a Vice Chairman were elected for a period of one year. ${ }^{11}$ An Executive Committee of five delegates was likewise appointed by the Board. ${ }^{12}$ Further steps were taken at this and subsequent meetings to provide permanent offices ${ }^{13}$ for the Board and to engage the services of a permanent staff for the Secretariat. Mr. Herbert Delafield, past President of the Associated Coffee Industries of America and for many years a prominent figure in the domestic coffee trade, was appointed Secretary of the Board. Mr.

${ }^{20}$ Article XXI reads as follows: "As long as the present Agreement remains in force, it shall prevail over provisions inconsistent therewith which may be contained in any other agreement previously concluded between any of the participating Governments. Upon the termination of the present Agreement, all the provisions which may have been temporarily suspended by virtue of this Agreement shall automatically again become operative unless they have been definitively terminated for other reasons."

${ }^{12}$ The United States Delegate, Mr. Paul C. Daniels, was elected Chairman; the Brazilian Delegate, Mr. Eurico Penteado, was elected Vice Chairman.

${ }^{12}$ The Salvadoran Delegate, Mr. Roberto Aguilar, was elected Chairman of the Executive Committee, which likewise includes the Delegates of Colombia, Guatemala, Brazil, and the United States.

${ }^{23}$ Due to the crowded conditions prevailing at the Pan American Union, it was necessary for the Board to seek office space elsewhere in Washington. After a few weeks of searching, very satisfactory quarters were obtained at 2400 Sixteenth Street, Washington, D. C., proper installations were made, and since July $I, 194 x$, all meetings of the Board have been held in its own independent offices. 
Enrique Lewis Comas, formerly Secretary of the Inter-American Financial and Economic Advisory Committee, was appointed Assistant Secretary.

In accordance with the Inter-American Coffee Agreement, the funds for the maintenance of the Board are contributed by the 15 participating governments, each producing country contributing an amount proportionate to its export quotas, and the United States contributing one third of the total budget. The budget for the initial quota year was set at $\$ 18,000$, and that for the quota year ending September 30, I942, at $\$ 24,000$.

Official minutes of the meetings of the Board are maintained, and copies provided to the delegates and their governments. These minutes are not made public, although the texts of resolutions adopted by the Board and explanatory press releases are made available after each meeting. The Board is likewise charged with the preparation of an annual report covering all of its activities and any other matters of interest in connection with the Coffee Agreement at the end of each quota year. These reports are for transmittal to each of the participating governments, but will likewise be made available to the general public.

\section{Major Problems So Far Confronted by the Inter-Amertcan Coffee Board}

The most important single function of the Inter-American Coffee Board relates, of course, to the adjustment of the coffee quotas in accordance with the needs of the market. Shortly after the first meeting of the Board in April, this question came up for discussion, and after some debate the Board approved a resolution on May 28, I94I, increasing the quotas for the United States market by $5 \%$ of the basic quotas, effective June I. During ensuing months a situation of increasing tightness developed in the domestic coffee market, accompanied by a rapid price advance, ${ }^{14}$ which eventually led to a further emergency increase of the quotas under Article VIII of the Agreement. In a resolution dated August 2, effective August II, the Board approved an emergency increase of the quotas by an additional $20 \%$ in an effort to ease the acute situation which had developed in the United States market, and which had become a source of increasing concern to the Office of Price Administration and Civilian Supply. There followed a period of uncertainty in the coffee market during the next two months, due to the apparent inconsistency between the increased size of the quotas and the attempt on the part of the producing countries to maintain the market through the minimum price system. Finally, after weeks of debate, agreements were reached unanimously by the Board at its meeting held on October 23, 1941. The quotas for the United States market were at that time set at $110 \%$ of the basic quotas, and at the same time the Board approved a declaration of policy to the effect that minimum prices would not be used in such a way as to control market prices or prevent normal fluctuations in the market.

While the difficult question of quota adjustments, briefly summarized above, was by far the most outstanding problem confronting the Inter-American Coffee Board

\footnotetext{
14 This price advance, with the consequent disturbances of the United States coffce market, was largely due to artificial price control measures taken in Brazil and Colombia, through the establishment of minimum prices for export.
} 
during the early months of its existence, a number of other problems arose which engaged the Board's careful attention. Without going into great detail, reference may be made to the following:

( $\mathrm{I}$ Prices and consumption. On April I7, I94I, at its first meeting, the Board issued a statement of its policy regarding prices and consumption. This statement pointed out the desirability of maintaining reasonable prices fair to producers, to promote the economic welfare of the producing countries, and at the same time announced the Board's purpose to maintain coffee prices at levels which would encourage increased consumption. ${ }^{15}$

(2) Statistics. The Board has been actively engaged in efforts to improve the accuracy, frequency and promptness of coffee statistics, not only in the United States but in each of the producing countries.

(3) Diverted shipments. The effective quota control established for the United States market, as contrasted with the relatively uncontrolled status of consuming markets outside the United States, soon brought about a higher level of prices within the United States than in other countries. Accordingly, it would have become profitable for coffee to be exported from a producing country under the quota for the world market, and subsequently diverted for sale in the United States at a higher price. A few instances of diverted shipments of this character actually occurred, particularly on the Canadian border. On May 15, I94I, the Inter-American Coffee Board issued a statement condemning this practice and indicated its intention to take effective steps to terminate it, in cooperation with the governments participating in the Inter-American Coffee Agreement. On September 18, I94ז, President Roosevelt signed an Executive Order which has prevented any recurrence of this evasion of the purpose and intent of the Coffee Agreement. ${ }^{16}$

(4) Shipping facilities. On July 24, 1941, the Board approved a resolution requesting the Government of the United States to exert every effort to maintain maritime facilities for the movement of coffee to the United States market in sufficient volume to fill the quotas established under the provisions of the Inter-American Coffee Agreement. In addition, in order to take advantage of available shipping space with the maximum efficiency, the Board has approved a resolution authorizing producing countries to export to the United States prior to the end of the quota year an amount not to exceed $15 \%$ of their respective quotas, to be charged against the quotas for the ensuing quota year.

There have been a number of other problems which the Board has had to confront during the first nine months of its existence, but space does not permit a detailed description of these. It should be pointed out, however, that any major problem confronting the international trade in coffee now can be referred to a continuing body of an international character, on which are represented the major

${ }^{15}$ Copies of this declaration, and of all other public statements and resolutions of the Inter-American Coffee Board referred to in this article, may be obtained on application from the Inter-American Coffee Board, 2400 Sixtcenth Street, Washington, D. C.

${ }^{10}$ Exec. Order of Sept. 18, 1941, Prescribing Regulations Pertaining to the Entry of Coffee into the United States from Countries Signatories of the Inter-American Coffee Agreement, 6 FED. REg. 4809 (I94I). 
producing areas as well as the major consumer. This organization is qualified to consider such problems in a rapid and efficient manner, as contrasted with uncoordinated negotiations between a number of different countries. The Inter-American Coffee Board has become established already as the central point for all important coffee problems of an international character.

\section{Summary and Conclusion}

The broad objectives of the Inter-American Coffee Agreement are set forth in the Preamble of the Agreement itself, wherein it is stated that "it is necessary and desirable to take steps to promote the orderly marketing of coffee, with a view to assuring terms of trade equitable for both producers and consumers by adjusting supply to demand." This broad objective has already been largely accomplished. There has been a healthy restoration in the price of coffee in the United States market, and yet by careful administration the price has been prevented from soaring to levels which would be unfair to consumers and possibly prejudicial to the maintenance or expansion of total consumption. The attainment of this broad objective has brought with it many practical, concrete advantages, some of which can already be evaluated fairly accurately. The purchasing power of the consuming public in the coffee-producing countries has already shown a marked increase. The added return from coffee sales has in turn stimulated general business improvement in those same areas. Increased dollar exchange made available by coffee exports to the United States market has in turn facilitated payment for American exports, and established a sounder basis for two-way trade. The acute shortages in dollar exchange which motivated severe types of trade and exchange control in many of these countries during the past decade have already largely disappeared. In a number of countries there has already been a marked improvement, not only in ability to pay outstanding dollar obligations, both commercial debts and long-term obligations, but in actual repayments. Unemployment in the producing countries has been diminished, wage scales have been maintained or raised, and various types of social benefits have ensued. The general internal prosperity of the producing countries improves fiscal revenues and strengthens their political, economic and social stability. These are practical and concrete achievements. They come at a time when much of the world is torn by war, and when uncertainty and instability are the rule of the day.

It is, however, in the general field of inter-American relations that the InterAmerican Coffee Agreement assumes a vital significance. It is an experiment in practical cooperation. It recognizes the fact that prosperity must be mutual to be enduring, and that both producers and consumers have an interest in the maintenance of stable trading conditions on equitable terms. The success of the Agreement is dramatic proof of the ability of the American republics to meet a common emergency and to work together toward a common end. As time goes on and conditions change, new needs may arise and modifications may be necessary; but the rapidity and effectiveness with which an emergency situation was met and brought under control in 1940 will stand as a landmark in the history of inter-American cooperation. 